he asks, then vacation pay can be paid in period, different from period of the part 4, paragraph 115 of the Code of Laws about Labour of Ukraine. It is thus useful to harmonize not only the period of leave by the employer and employee but the period of vacation pay as well.

In order to avoid misunderstandings with controlling bodies, we recommend to add the paragraph 115 of the Code of Laws about Labour of Ukraine with the part 5: «In case when an employee and employer reach agreement about taking annual paid leave (part of the leave) against leave schedule and /or more quickly (less, than 14 calendar days before leave), vacation leave is paid in term, agreed between an employee and employer but no later than the next part of the wage».

\title{
References:
}

1. Konstytutsiia Ukrainy vid 28 chervnia 1996 r. \#254k. URL: https://zakon.rada.gov.ua/ laws/show/254\%D0\%BA/96-\%D0\%B2\%D1\%80 (accessed 19.06.2019).

2. Pro ratyfikatsiiu Konventsii Mizhnarodnoi orhanizatsii pratsi \#132 (perehlianutoi) 1970 roku pro oplachuvani vidpustky Zakon Ukrainy vid 29 travnia 2001 r. \#2481. URL: https://zakon.rada.gov.ua/laws/show/2481-14 (accessed 19.06.2019).

3. Konstytutsyia Latvyiskoi Respublyky. URL: https://www.president.lv/ru/latviiskayarespublika/konstituciya-latvii (accessed 25.06.2019).

4. Labklājības ministrija. URL: http://www.lm.gov.lv/rus/otraslevaya-politika/rabota/0-2018-1009-17-32-16 (accessed 25.06.2019).

5. Konventsiia pro oplachuvani vidpustky \#132 (perehlianuta u 1970 rotsi) vid 24 chervnia 1970 r. \#132 URL: https://zakon.rada.gov.ua/laws/show/993_022 (accessed 19.06.2019).

6. Lyst Ministerstva sotsialnoi polityky vid 05 sichnia 2012 r. \#7/13/133-12. URL: https://zakon.rada.gov.ua/rada/show/v0007739-12 (accessed 19.06.2019).

7. Kodeks zakoniv pro pratsiu Ukrainy vid 10 hrudnia 1971 r. \#322. URL: https://zakon.rada.gov.ua/laws/show/322-08\#n561 (accessed 19.06.2019).

\section{DIFFERENCES IN THE FUNDAMENTAL RIGHTS UNDERSTANDING: DOES THE PROBLEM IN THE EUROPEAN UNION EXIST?}

\section{Olena Rym $^{1}$}

DOI: https://doi.org/10.30525/978-9934-588-11-2_62

The social component in the European Union's policy is on the rise. Thus, the Lisbon Treaty clearly has it that the EU wants to have social Europe, and with this in view the following international legal tools will be used: the European Convention for the Protection of Human Rights and Fundamental Freedoms (hereinafter referred to as the Convention) and the European Social Charter. Thus, the EU shall take into account the interpretation of the fundamental social rights in the way suggested by the European Court of Human Rights (hereinafter referred to as the ECtHR).

\footnotetext{
${ }^{1}$ Ivan Franko National University of Lviv, Ukraine
} 
The practice of referring to the Convention is not new in the European Union. Before the Court of the European Union developed its own human rights catalogue in the Charter of Fundamental Rights of the European Union (hereinafter referred to as the Charter), it had been using the provisions of the Convention to which it attached great importance while considering respective case types. Thus, thanks to the pragmatic approach of this European institution, the Convention became a particularly convenient tool for protecting human rights, common for all the EU Member States, and played a special role at all the stages of the establishment and development of human rights protection in the EU, having transformed into an important factor of integration processes occurring in Europe. For example, just within the period from 1975 to 1998 the Court of the EU cited the Convention in more than 70 of its judgments [1, p. 645].

In spite of the fact that nowadays the Charter of Fundamental Rights of the European Union is the core element in the system of rights protection at the EU level, the Court of the EU cannot but work in accordance with the legal procedures adjacent to the Community in this field. Moreover, it must interpret fundamental rights in accordance with the constitutional traditions that are common for the EU Member States. In this context it is important that the content and the scope of the fundamental rights in the course of their interpretation by different European institutions do not differ. Efficient dialogue of the Court of the EU with national courts and the European Court of Human Rights constitutes a clear pre-condition for common understanding of the essence of fundamental rights in Europe.

Taking this into account, we are drawing attention to the provisions of clause 2 of Art. 6 of the Treaty on the EU. Under it, the Union joins the European Convention for the Protection of Human Rights and Fundamental Freedoms. Hence, the fundamental rights secured by the Convention and stemming from constitutional traditions that are common for the Member States shall constitute the general principles of the law of the Community.

Though the EU is not an official party to the Convention, the Charter and the Convention co-exist within acquis communautaire, with the only difference that the former is applied by the Court of the EU in connection to the actions of the European Union, while the latter - by the European Court of Human Rights in relation to activities of the Member States. However, after 2009, that is after the Charter of Fundamental Rights of the European Union became binding, the Court of the EU still keeps applying provisions of the Convention and the practice of the ECtHR, but only as an additional tool for interpreting provisions of the Charter [2, p.155].

By 2007 the practice of the Court of the EU on the protection of fundamental rights testifies to frequent use of the precedent practice of the ECtHR. And the Court of the EU has stressed the autonomy and priority nature of the legal system of the European Union in the protection of fundamental rights. In particular, in its practice the Court of the EU follows the trend of focusing exclusively on the Charter in cases related to fundamental rights. In spite of this, the Convention has been playing and keeps playing an important role in the legal procedure of the EU. At the same time, it should be stressed that the Charter of Fundamental Rights of the European Union 
has also influenced the interpretation of fundamental rights by the European Court of Human Rights. Such mutual influence can yield synergy between these institutions. And the main goal of cooperation should be improved mechanism of fundamental rights protection in Europe in general. And the practice of the ECtHR should ensure external examination of the commitments of the EU Member States, while the activity of the Court of the EU would serve as an internal element of the mechanism of fundamental rights protection of the EU [3, p. 23-24].

Though the EU joined the Convention only in a declarative way, provisions of Art. 52 and 53 of the Charter fix clear rules for interaction between the Charter and the Convention. To be more specific, clause 3 of Art. 52 of the Charter indicates that if the Charter contains the rights secured by the Convention, then the sense and scope of those rights also correspond to the ones established by the Convention. At the same time, this clause does not envisage any obstacles on the way to ensuring a wider protection of fundamental rights at the EU level than the one established within the Convention. Thus, the necessary accordance between the Charter and the Convention are ensured, as well as similarity of understanding and application of fundamental rights in the multi-layered system of their protection, that now exists in Europe, is achieved. At the same time, there arises a threat for the autonomy of the EU law.

Prior to the conclusion of the Lisbon Treaty, the European Court of Human Rights in a number of its judgments substantiated the doctrine of equivalent protection of fundamental rights. And interference into the field of the EU competence, if the legal order of the Union ensures equivalent protection of such rights, must be limited. The ECtHR is convinced that equivalence of protection presupposes the possibility for appealing acts of the EU institutions, that infringe fundamental rights, in the Court of the EU. And equivalent protection itself for the Strasbourg Court stands for the protection that is commensurate with the one envisaged by the Convention, but not necessarily identical to it $[4$, p. 6].

The same as the ECtHR, the Court of the EU supports teleological approach that interprets the norms of the law on the basis of the goals set [5, p. 48]. In case with the ECtHR, the core goal of its activity is to ensure observance by the states of the rights provided for by the 1950 European Convention on the Protection of Human Rights and Fundamental Freedoms. And when it comes to the Court of the EU, there are several of such goals, including ensuring of the functioning of the common domestic market and simultaneous observance of human rights. Hence, the need for looking for a balance of confronting interests in each conflict. It would be unfair and wrong to state that human rights are not a priority for the Court of the EU.

To sum up, it should be stated that similar understanding of the content of rights enshrined in the Charter of Fundamental Rights of the European Union and the European Convention for the Protection of Human Rights and Fundamental Freedoms is extremely important. Absence of unity may lead to obstacles on the way to implementation and protection of respective rights as well as prevent further European integration. 


\title{
References:
}

1. Douglas-Scott, S. (2006). A tale of two courts: Luxembourg, Strasbourg and the growing European human rights acquis. Common Market Law Review, vol. 43, issue 3, pp. 629-665.

2. Falalieieva, L. H. (2017). Pryiednannia Yevropejs'koho Soiuzu do Konventsii z prav liudyny: pravova pozytsiia Sudu. [Accession of the European Union to the Convention on Human Rights: the legal position of the Court]. Sudova apeliatsiia, no 3, pp. 151-161.

3. Lenaerts, K. (2018). Speech of the President of the Court of Justice of the European Union, opening of the judicial year, 26 January 2018. Annual report 2018 - European Court of Human Rights, pp. 23-35.

4. Costa, J.P. (2008). The Relationship between the European Convention on Human Rights and European Union Law - A Jurisprudential Dialogue between the European Court of Human Rights and the European Court of Justice. Lecture at the King's College (Inner Temple). London, 7 October 2008, pp. 1-10.

5. Ispolinov, A. S. (2012). Poisk balansa mezhdu svobodami vnutrennieho rynka i pravami chieloveka $\mathrm{v}$ sudiebnoj praktyke ES [Finding a balance between domestic market freedoms and human rights in the EU judicial practice]. Zhurnal zarubiezhnoho zakonodatel'stva i sravnitel'noho pravovedeniia, no 6, pp. 38-49. (in Russian)

\section{THE IDENTIFICATION OF A LAWYER WITH A CLIENT THROUGH THE PRISM OF VIOLATIONS OF OTHER GUARANTEES OF THE PRACTICE OF LAW}

\author{
Ruslan Skrynkovskyy ${ }^{1}$ \\ Lyubomyr Sopilnyk ${ }^{2}$ \\ Rostyslav Sopilnyk ${ }^{3}$
}

DOI: https://doi.org/10.30525/978-9934-588-11-2_63

According to Art. 23 of the Law of Ukraine «On the Bar and Practice of Law» (as of 05.07.2012, № 5076-VI) [1], the professional rights of the lawyer, his honour and dignity are guaranteed and protected by the current Constitution of Ukraine [2], this Law [1] and other applicable laws of Ukraine, in particular: 1) interference with the activity of a lawyer, including any possible obstacles to the practice of a lawyer, is prohibited; 2) it is forbidden to insist and demand (require) a lawyer to disclose any information (documents) that are advocate secrets [3];3) it is forbidden to interfere with the legal position of the lawyer, in private (personal) communication between the lawyer and the client, as well as to identify the lawyer with the client [1].

Given the above, it should also be noted that, in recent years, in Ukraine, in view of the political circumstances, lawyers have to defend those guilty of forced crackdown of Euromaidan, persons involved in resonant crimes against members of the Revolution of Dignity, as well as represent different parties in court, in particular,

\footnotetext{
${ }^{1}$ Lviv University of Business and Law, Ukraine

${ }^{2}$ Lviv University of Business and Law, Ukraine

${ }^{3}$ Lviv University of Business and Law, Ukraine
} 